Article

\title{
Efficiency of Different Integrated Agriculture Aquaculture Systems in the Red River Delta of Vietnam
}

\author{
Nguyen Van Huong ${ }^{1,2, *}$, Tran Huu Cuong ${ }^{1}$, Tran Thi Nang Thu ${ }^{3}$ and Philippe Lebailly ${ }^{2}$ \\ 1 Faculty of Accounting and Business Management, Vietnam National University of Agriculture, Hanoi, \\ Vietnam; trancuong@vnua.edu.vn \\ 2 Economics \& Rural Development, Gembloux Agro-Bio Tech, University of Liège, Gembloux 5030, Belgium; \\ philippe.lebailly@uliege.be \\ 3 Faculty of Fisheries, Vietnam National University of Agriculture, Hanoi, Vietnam; \\ trannangthu@vnua.edu.vn \\ * Correspondence: nghuonghd76@gmail.com
}

Received: 20 November 2017; Accepted: 30 January 2018; Published: 13 February 2018

\begin{abstract}
Integrated Agriculture Aquaculture (IAA) is characteristic with diversity of small-scale production systems in the Red River Delta, Vietnam where most integrated aquaculture systems are closely associated to the VAC model, an ecosystem production that three components: garden (V), pond (A) and livestock pen (C) are integrated. These VAC systems effectively use all the available land, air, water and solar energy resources, and also effectively recycle by-products and waste for providing diversified agricultural products to meet the complex nutritional demands of rural communities. The IAA systems are dynamic, diverse and subject to economic and environmental changes. By investigating 167 aquaculture households, the traditional VAC, New VAC, Animal Fish (AF) and Commercial Fish (FS) systems are identified as four existing IAA systems. This paper presents the main characteristics and economic efficiency of these IAA systems. The study's results indicate clear evidence that the traditional VAC system and New VAC system are the most efficient and effective models. The findings of this study have shed light on the important role of integrated aquaculture systems to food security and economic development of households and local communities. The VAC systems are likely to propose for improving household food security and developing the local economy.
\end{abstract}

Keywords: efficiency; integrated aquaculture systems; VAC; Red River Delta

\section{Introduction}

Freshwater aquaculture is an important component of the supply of animal-based protein, amino acids, fatty acids, minerals and vitamins in the diets of predominantly poor populations in the developing countries of South East Asia [1-5]. While the rapid growth of aquaculture and broader development has occurred in the past decades, increasing unpredictability associated with climate change and greater volatility in food prices and food security are still problematic. Climate change is expected to bring particularly severe impacts to the populated deltas of Asia where the freshwater aquaculture systems are the most prevalent, if well managed or further developed, they might play an important part in adaptation approaches for enhancing social-eco-logical resilience [6].

The dynamicity of freshwater aquaculture systems is diversified from small to large-scale with increasing commercial products [7]. Developing aquaculture has targeted for the poverty reduction strategy and/or a key part of macro-economic growth in many developing countries. The renewed approach in which various types of aquaculture could contribute to poverty alleviation at household, community and national levels is critical [8]. In Vietnam, at first, a typical aquaculture system is named 
as the VAC system with ' $\mathrm{V}$ ' for garden (Vuon), ' $\mathrm{A}$ ' for pond $(A o)$ and ' $\mathrm{C}$ ' for livestock pen (Chuong) from which a large part of the system's production is utilized for the household subsistence in the Red River Delta. Taking into consideration of economic objectives, the systems have gradually developed toward market-orientation for improving the farmers' income. Thus, a large number of products has been traded on markets for the families' cash income.

Economies of scale on fish production is still debatable in the literature. It was found that, a large scale of aquaculture production is not significant in some developed countries because small farms can be managed more intensively than medium and large ones [9]. Whereas, freshwater aquaculture in developing countries is acknowledged to contribute to a sustainable method to assure food security, to alleviate poverty because of its product diversification $[4,5,10]$. Conversely, this argument is contrasts with the case of Solomon Island where only wealthier households capable to access small scale of aquaculture [11].

Additionally, in many parts of Asia where fish has traditionally been a key dietary item, aquaculture production faces many challenges. For example, agricultural intensification pushes an additional pressure on wild fish stocks through the modification of aquatic habitats, intensive use of agrochemicals, and water surface exploitation for rice irrigation [6]. Many small scale producers constrained to market access and new development trends acquire appropriate policies that are still a struggle of Asian developing countries [12]. Agriculture and food industry have achieved significant advances in the past decades. However, their development has not really accomplished the needs of health and nutrition, and in some cases, they have made a substantial collateral losses in agricultural biodiversity [13].

The northern Vietnamese VAC system shares many features in common with the south Chinese pond-dyke system, having developed similarly in response to extremely high demographic pressure on land and resources experienced in the Red River Delta provinces $[10,14,15]$. Directly integrated semi-intensive forms of aquaculture (in which wastes and by-products from some agricultural sub-systems within the farm are reused as inputs into others) are extremely attractive in terms of their ecological sustainability. Aquaculture plays a principal component in integrated agriculture aquaculture system (IAAS) [16]. Previous studies show that freshwater aquaculture is a strategy to improve nutritional standards as well as generate income to small-scale farming households $[17,18]$.

Misui, H. and H. Horiuchi [19] classified fourteen types of farming enterprise combinations in the VAC system hereunder, VAC, VA, VC, AC, V, A, C, VAC+rice, VA+rice, VC+rice, AC+rice, V+rice, $\mathrm{A}+$ rice, and $\mathrm{C}+$ rice. The VAC classification is often improperly used by researchers and specialists in both Vietnam and Japan. The most appropriate approach to classify the VAC farming systems is based on agricultural income at the household level.

In past decades, there have been a number of studies focused on the outcome of aquaculture production systems as health and nutritional sources to fishing families and rural communities [20]. The findings identify major benefits of freshwater aquaculture as direct consumption of fish; income generated to purchase other food that is cheaper in markets. It has enhanced nutrition of the fish farming family intakes [4,21-25]. In other aspects, the availabilities of fresh fish with cheaper prices benefit urban communities and local people. Being as workers, poor farmers would earn wages and salaries for their food affordability.

Aquaculture is being recognised as an important way of enhancing food production and nutrition [26,27]. In Vietnam, freshwater fish contributes to $12.4 \%$ of the $29 \mathrm{~g} \cdot \mathrm{capita}^{-1} \cdot \mathrm{day}^{-1}$ animal-based protein supply [28], of which $37 \%$ is supplied by the cyprinid and cichlid species and mainly produced through aquaculture [29]. However, the important role of IAA systems is normally under-valued and their potential for augmentation usually overlooked in favour of large-scale commercial ventures, which are more attractive for support by development institutions and policy makers [10]. While stand-alone aquaculture is risky venture and it is not an option for resource-poor farmers, integrated aquaculture systems are operated with the aim of maximising resource utilisation and reducing risk. The purposes of IAA are increased diversification, intensification, improved natural resource efficiency, increased productivity, and increased sustainability. 
This paper aims at assessing the integrated aquaculture systems in the Red River Delta of Vietnam. Then, it turns to discuss the efficiency and effectiveness of these existing integrated aquaculture systems. The study also analyzes the contribution of those systems to local households' income and food security. The findings of this research reveal the role of IAA systems and propose a sustainable aquaculture system for the local communities' food security and economic development.

\section{Materials and Methods}

\subsection{Study Site and Data Collection}

\subsubsection{Study Site}

Hai Duong is located centrally in the Red River Delta, Vietnam where agricultural practices are dominant with rice based farming system which is a traditional and principal source of staple food as well as income for rural farmers. Alternative land use and livelihood options such as aquaculture, fruit production and livestock have performed as integrated components of the IAA systems which created more cash income, food and foodstuffs to meet daily subsistence needs [30]. The province has promoted freshwater aquaculture as a main strategy to develop its economy. Therefore, local authorities have approved farmers to convert unproductive and inefficient low-flooding paddy land into specialized/concentrated zones of freshwater aquaculture [31-33].

The current trend increases fish production by intensifying and expanding the areas under aquaculture production and this trend can be maintained and encouraged (see Figure 1). Generic technologies used to intensify the existing production systems are in place, and it is mainly socio-economic and institutional issues that will significantly foster greater contributions from aquaculture to rural development. In Hai Duong, the freshwater aquaculture production system has become complex and diverse, not only at the scale of the ponds, the level of fish intensification, techniques, and technology but also in the integration of other agricultural operations such as livestock and crop cultivation. Because fish production can be integrated within agriculture on current agricultural lands in smallholder and commercial farms, the expansion of freshwater aquaculture in the province has great potential. Therefore, freshwater aquaculture can be assessed to have a key role in food production systems by observing the boom of fish production in the province since its re-establishment in 1997 (Haiduong was re-established in 1997 from the before province of HaiHung-a merged Hung Yen and Hai Duong province). Regarding to aquaculture's contribution to food systems and rural economic development, it is, perhaps, not surprising that aquaculture production has been the fastest growing sub-sector of the agriculture in Hai Duong, since the 1980s. Data also show that aquaculture production accounted for approximately $2.7 \%$ (in 1996) and $12 \%$ (in 2014) [31-33] of the total agricultural value in the province.

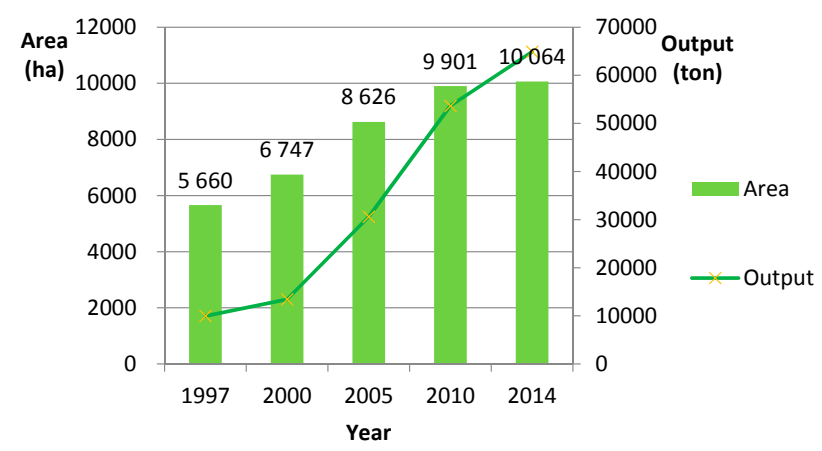

Figure 1. The Area and Production of Freshwater Aquaculture in Hai Duong province (1997-2014). Source: Hai Duong Statistical Book, 1999, 2005, 2014. 
In Hai Duong, aquaculture has been considered an important economic sector due to its rapid growth. Freshwater aquaculture is unique and quite notable because of its geographic as an inland area (no coastlines) of the Red River Delta (see Figure 2). Moreover, the VAC system has developed for a long time and is familiar to farmers.

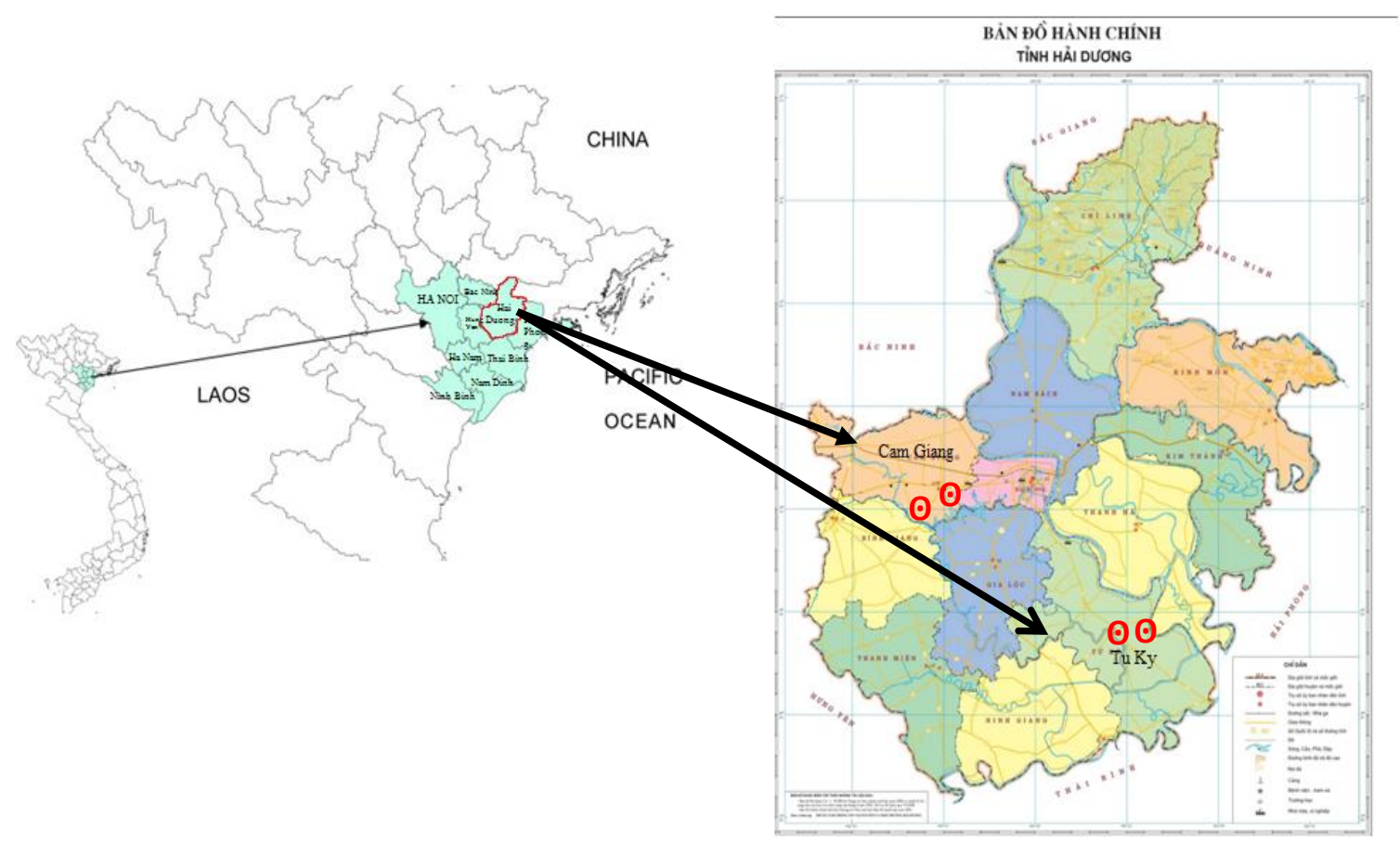

Figure 2. Site selection of two districts in Hai Duong. Source: Vietnam department of survey and mapping 2015.

\subsubsection{Data Collection}

Due to limitations and lack of data about aquaculture systems, the stratified sampling method was applied for the study. The two rounds of household survey were conducted at 4 villages of HaiDuong province namely Lac Duc, Thuong Son, HoaBinh and An Lai in 2015 and 2016. Before the first data collection started in 2015, key informant group discussions were applied for classifying the existing types of aquaculture households at each village. Three emerging types of aquaculture households have been identified: (1) households only engaged in fish production (fish households), (2) households engaged in livestock husbandry and fish production (Animal/Fish households), (3) households engaged in livestock husbandry, garden and fish production (New VAC households). This survey has focused on concentrated/specialized zones of aquaculture production outside villages. Interviews were carried out with 151 aquaculture households selected from the lists provided by local authorities. In 2016, the second survey was implemented to more focus on assessment of traditional VAC households inside the village. However, the aquaculture households have not been registered and reported in official statistics, by discussing with local communities, all 16 fish households identified as operating the traditional VAC system were covered in the second survey. The sample distribution was presented in the Table 1. 
Table 1. Samples of fish households (HHs) selected in Hai Duong province.

\begin{tabular}{cccccccc}
\hline & Location & & Fish HHs & $\begin{array}{c}\text { Animal/Fish } \\
\text { HHs }\end{array}$ & New VAC HHs & $\begin{array}{c}\text { Traditional VAC } \\
\text { HHs }\end{array}$ & Total \\
\hline District & Commune & Village & & & & & \\
\hline \multirow{2}{*}{ Cam Giang } & Cam Doai & HoaBinh & 13 & 13 & 10 & 5 & 41 \\
& Cam Dong & An Lai & 8 & 18 & 9 & 3 & 38 \\
\hline \multirow{2}{*}{ Tu Ky } & Subtotal & & $\mathbf{2 1}$ & $\mathbf{3 1}$ & $\mathbf{1 9}$ & $\mathbf{8}$ & $\mathbf{7 9}$ \\
\hline & Hung Dao & Lac Duc & 19 & 15 & 7 & 4 & 45 \\
& Tai Son & Thuong Son & 11 & 19 & 9 & 4 & 43 \\
\hline & Subtotal & & $\mathbf{3 0}$ & $\mathbf{3 4}$ & $\mathbf{1 6}$ & $\mathbf{8}$ & $\mathbf{8 8}$ \\
\hline
\end{tabular}

\subsection{Data analysis}

In this study, multivariate factor analysis was employed to analyze the cross-relationships between aquaculture production systems to identify any major underlying factors between these relationships. ANOVA is used to assess potential differences in a scale-level dependent variable by a nominal-level variable having two or more categories.

In oder to achieve comprehensive findings, a picture of the farm operation as a whole was managed to evaluate. Indicators and derived measures for annual whole-farm evaluation are adapted to McConnell and Dillon (1997) [34]. The analysis measured terms of farm performance from records in the following areas: Farm Gross Margin (E), Farm Net Actual Returns (F), Farm Net Sustainable Returns (G), Family Farm Available Income (H), Family Farm Sustainable Income (I), and Total Available Family Income (J). While these indicators are desirable because E, F, G, H, I, and J are adequate records and over time to indicate the degree of variability in the performance of the subject farm, they do not in and of themselves provide any basis for comparing a farm's income levels to those of other farms. If whole-farm comparison is introduced at this point, the results are summarized in Table 2. Thus, fish farms would be compared in terms of the measures E, F, G, H, I, J with other farms in the villages or area having a similar size, soil, water supply, etc. but not necessarily the same mix of activities.

Table 2. Indicators and Derived Measures for Annual Whole-farm Evaluation.

\begin{tabular}{cccc}
\hline Measure & Calculation & Notes & Notes \\
\hline A. & All Outputs / Returns (Pooled) & & \\
B. & All Purchased Activity Direct Inputs (Pooled) & & Depreciation recorded in D below \\
C. & All Farm Fixed Costs (except Depreciation) & & \\
D. & All Capital Depreciation & A-B & Depreciation not yet charged. \\
E. & Farm Gross Margin & E-C & Depreciation charged; system now sustainable. \\
F. & Farm Net Actual Returns & F-D & But only if depreciation is not covered. \\
G. & Farm Net Sustainable Returns & H = F & Long-term Sustainable farm income. \\
H. & Family Farm Available Income & I = G & S is non-farm income, here assumed to be zero. \\
I. & Family Farm Sustainable Income & (H or I) + S & Total Available Family Income
\end{tabular}

\section{Results and Discussion}

\subsection{Diversification of Integrated Agriculture Aquaculture Systems for Food and Foodstuffs Production}

According to findings of the survey, integrated aquaculture systems have been developed by many households since 1980s. Based on the current situation of households, the study defines four prevalent aquaculture production systems as follows: (i) Intensive orchard very low input aquaculture within residential area - traditional VAC system; (ii) Intensive orchard-low input aquaculture outside residential area-New VAC system; (iii) Semi-intensive orchard medium input aquaculture outside 
residential area (Animal + Fish production) - AF system; (iv) Extensive orchard high input aquaculture (commercially intensive fish production)—FS system (Appendix A1).

Traditional VAC system appears as low-input aquaculture located within the village. Most households perform this model based on their own experiences in aquaculture production in a connection to rice production and medium animal husbandry, and small scale horticulture. It is found that households have an average of $878 \mathrm{~m}^{2}$ of fishponds, $131 \mathrm{~m}^{2}$ of fruit trees, and 5-15 pigs (see Appendix A1). Compared to other systems, this is the smallest scale of the production. The traditional VAC system uses mostly food wastes animal manure as an input for production. More interestingly, there exists diverse fruit production like banana, orange, papaya, peach, litchi, longan and apple that can supplement to household income. It is also found the households in this model engage more on off-farm income activities than those in other models. It allows them to combine residues from off-farm products to on-farm production with lower costs. For example, the wastes from traditional alcoholic beverage production, and rice milling service can utilize for feeding fish and pig production.

New VAC system is a transformation of the traditional VAC system, but this model is developed in larger scale of fishpond and focus also on fruit production. So this model is usually found outside the village with less residential density. Average farm scale of the households is about $2344 \mathrm{~m}^{2}$ of fishpond, and $515 \mathrm{~m}^{2}$ of fruit trees. It has the largest size of homestead compared to the traditional VAC and other systems described below (see Table 3). Furthermore, households of this model not only apply more technology and advanced techniques on fish farming but also diversify more husbandry products than those in the traditional VAC system. Pig and poultry production are the most common, cattle are also added. However, number of cattle is not much, just 1-3 cattle per farm.

Animal-fish (AF) system mainly focuses on a combination between fish and larger pig or poultry production. Fruit orchards and rice production are likely less paid attention because of inadequate forces of labor. The findings reveal that average agricultural land per household $\left(6588 \mathrm{~m}^{2}\right)$ in this model is about 1.5 to 2 times higher than that in the New VAC and the traditional VAC, meanwhile average area of fruit trees $\left(317 \mathrm{~m}^{2}\right)$ is much less than that in the New VAC and paddy land $\left(2220 \mathrm{~m}^{2}\right)$ is less than that of the traditional VAC. Additionally, unlike the previous models, major production inputs like pellet feed, veterinary chemicals of this model come from materials, feeding shops/suppliers in local markets. Therefore, the households rely more on markets for both inputs and output of their production.

Fish system (FS) is the most commercially intensive production of fish comparing to other systems. With the largest scale of farm size, it sets a high priority on fish production. The area of aquaculture land $\left(5200 \mathrm{~m}^{2}\right)$ accounts for $77.5 \%$ of total agricultural land, while that in the animal fish model is $4360 \mathrm{~m}^{2}$ $(66.2 \%)$, following by $2340 \mathrm{~m}^{2}(55.6 \%)$ in the New VAC and $878 \mathrm{~m}^{2}(23.8 \%)$ in the traditional VAC. Households of the system own at least 2 fishponds for their fish production. A small pond $\left(200-300 \mathrm{~m}^{2}\right)$ is for nursery stage of fingerlings, and the larger ponds are for the fish grow out. The fish are high market value species for the best economic return. In this system, paddy land is the lowest because most of it has converted for aquaculture purposes. Therefore, the scale expansion of this model within the study sites (for communes) cannot go further due to restriction of land conversion regulated by local government.

Among those systems, the traditional VAC system is most like a self-subsistence model because fish is harvested regularly for home consumption reaching to the largest $(52.9 \mathrm{~kg} / \mathrm{sao})$ and it effectively utilizes resources available in the agricultural practices within the household. In fact, the location of the pond closes to the resident houses, which creates a combination between aquaculture, and livestock production as well as between garden and livestock production. For example, livestock manure is used for feeding fish or fertilizing vegetables. Otherwise, pond provides water for irrigating the garden, especially vegetables in the backyard garden. Both perennial and annual crops are planted to provide year-round food to the households and surplus of products for the sale in markets. 
Table 3. The status and characteristics of fish farms in Hai Duong province.

\begin{tabular}{|c|c|c|c|c|c|c|c|c|c|}
\hline \multirow[b]{2}{*}{ Age } & \multirow{2}{*}{$\begin{array}{l}\text { Unit } \\
\text { Year }\end{array}$} & \multicolumn{2}{|c|}{ FS System $(\mathrm{N}=51)$} & \multicolumn{2}{|c|}{ AF System (N=65) } & \multicolumn{2}{|c|}{ New VAC System (N=35) } & \multicolumn{2}{|c|}{ Traditional VAC System $(\mathrm{N}=16)$} \\
\hline & & 52.1 & $(9.79)$ & 52.5 & $(8.35)$ & 55.8 & $(8.36)$ & 57.00 & $(4.35)$ \\
\hline Household size & People & $3.02^{\mathrm{a}}$ & (1.09) & $3.80^{\mathrm{a}}$ & (1.12) & 3.51 & $(1.40)$ & 3.63 & (1.71) \\
\hline Number of labourers & Labor & 2.45 & $(0.92)$ & 2.86 & $(1.10)$ & 2.66 & $(1.45)$ & 2.63 & $(0.96)$ \\
\hline Agriculture land & $\mathrm{Sao}^{(\#)}$ & $18.7^{\mathrm{a}}$ & $(9.10)$ & $18.3^{\mathrm{a}}$ & $(7.76)$ & $11.7^{\mathrm{b}}$ & $(3.82)$ & $10.25^{\mathrm{b}}$ & $(2.29)$ \\
\hline Homestead land & $\mathrm{m}^{2}$ & $353.0^{\mathrm{a}}$ & $(271)$ & $512.3^{\mathrm{b}}$ & $(430)$ & 459.5 & $(228)$ & $320.00^{\mathrm{a}}$ & $(109)$ \\
\hline Paddy land & $\mathrm{Sao}^{(\#)}$ & $4.20^{\mathrm{a}}$ & $(3.48)$ & $6.17^{\mathrm{b}}$ & $(3.10)$ & $5.20^{\mathrm{b}}$ & $(3.42)$ & $7.81^{\mathrm{c}}$ & $(2.14)$ \\
\hline Area of fruit trees & $\mathrm{m}^{2}$ & $230.0^{\mathrm{a}}$ & $(371)$ & $317.2^{\mathrm{a}, \mathrm{b}}$ & $(600)$ & $515.6^{\mathrm{b}}$ & $(878)$ & $131.25^{\mathrm{a}}$ & (76.58) \\
\hline Number of fruit trees & Tree & 36 & $(56.00)$ & $45^{\mathrm{a}}$ & (64.75) & $103^{\mathrm{b}}$ & $(171.20)$ & $17^{\mathrm{a}}$ & $(7.85)$ \\
\hline Number of animals raised & Heads of animals & $23^{\mathrm{b}}$ & $(26.36)$ & $188^{\mathrm{a}}$ & $(234.4)$ & $39^{\mathrm{b}}$ & $(36.01)$ & $64.69^{c}$ & $(17.86)$ \\
\hline Area of aquaculture land & $\mathrm{Sao}^{(\#)}$ & $14.49^{\mathrm{a}}$ & $(9.58)$ & 12.12 & $(7.01)$ & $6.51^{\mathrm{b}}$ & $(2.46)$ & $2.44^{\mathrm{c}}$ & $(0.63)$ \\
\hline Number of owned ponds & Ponds & $2.27^{\mathrm{a}}$ & $(1.56)$ & $1.88^{\mathrm{ac}}$ & $(0.89)$ & $1.34^{\mathrm{c}}$ & $(0.48)$ & $1.00^{\mathrm{b}}$ & 0.00 \\
\hline Experience in aquaculture & Year & 16.5 & $(7.23)$ & $17.6^{\mathrm{a}}$ & $(7.27)$ & $14.1^{\mathrm{b}}$ & $(4.85)$ & 17.31 & $(2.02)$ \\
\hline Stocking density & Fish $/ \mathrm{m}^{2}$ & $1.55^{\mathrm{a}}$ & (1.11) & $1.62^{\mathrm{a}}$ & $(1.15)$ & 1.49 & $(0.89)$ & 1.51 & $(0.35)$ \\
\hline Kinds of fish & Fish/stocking & $4.31^{\mathrm{a}}$ & $(1.22)$ & $4.37^{\mathrm{a}}$ & $(1.18)$ & $4.31^{\mathrm{a}}$ & (1.39) & $6.13^{\mathrm{b}}$ & $(0.88)$ \\
\hline Production cycle time & Months & $9.80^{\mathrm{a}}$ & $(2.59)$ & $10.50^{\mathrm{a}}$ & $(1.88)$ & $10.70^{\mathrm{a}}$ & $(2.03)$ & $12.00^{\mathrm{b}}$ & $(0.00)$ \\
\hline
\end{tabular}

${ }^{(\#)} 1$ sao $=360 \mathrm{~m}^{2}$. Different superscripts. $\left.{ }^{\mathrm{a}, \mathrm{b}, \mathrm{c}}\right)$ denote significant difference between means within rows $(p<0.05)$. Parentheses are standard deviations. Source: survey, $2015-2016$. 
In Hai Duong, the VAC system has initially recognized and promoted since 1980s. It has contributed to the local food production system with diversity of products and nutrient. By the time, the traditional VAC system (model) has been modified and improved in other "hybrid" aquaculture systems in which fish ponds, livestock, and orchards have moved from the residential areas to the rice field areas and the VAC intensification and development has been more commercial with more external inputs usage from markets. In recent years, the province has made considerable changes of its agricultural production and outputs. While cereal production represents a downward trend before rising to 842,826 tons in 2000 , there has been a sharp increase in the production of vegetable and fruit crops, livestock, and fish. The gross output of vegetables and fruit crops rose from 315 and 51 thousand tons in 1997 to 657 and 192 thousand tons in 2014, respectively. The eggs increased dramatically from 72.5 million in 1997 to 310 million in 2014 [31-33]. This period also witnessed a drastic increase in the production of pig and poultry, from 35,895 and 7524 tons in 1997 to 90,575 tons and 27,421 tons in 2014, respectively (Figures 3 and 4).

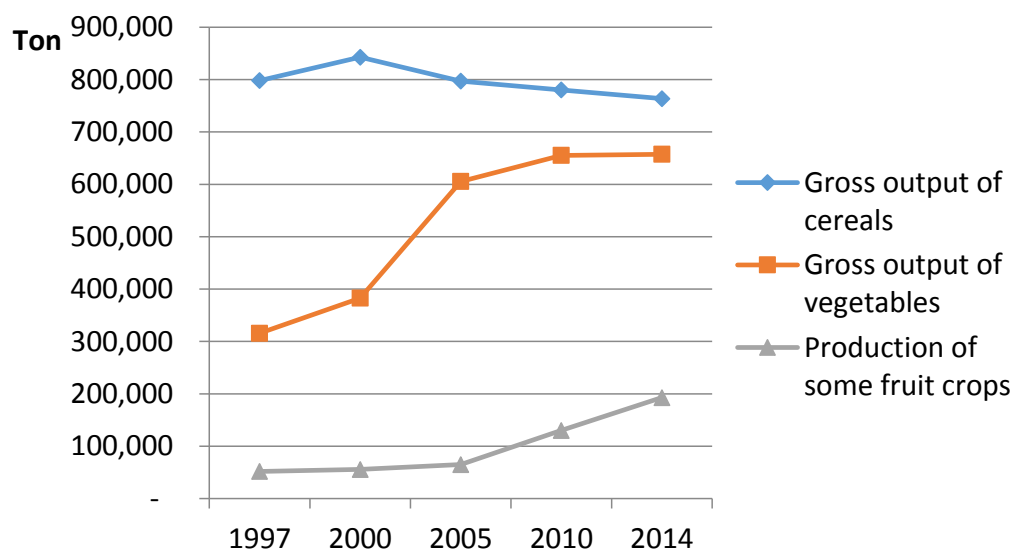

Figure 3. Changes in the gross output of different crop cultivation in Hai Duong (1997-2014). Source: Hai Duong Statistics Office.
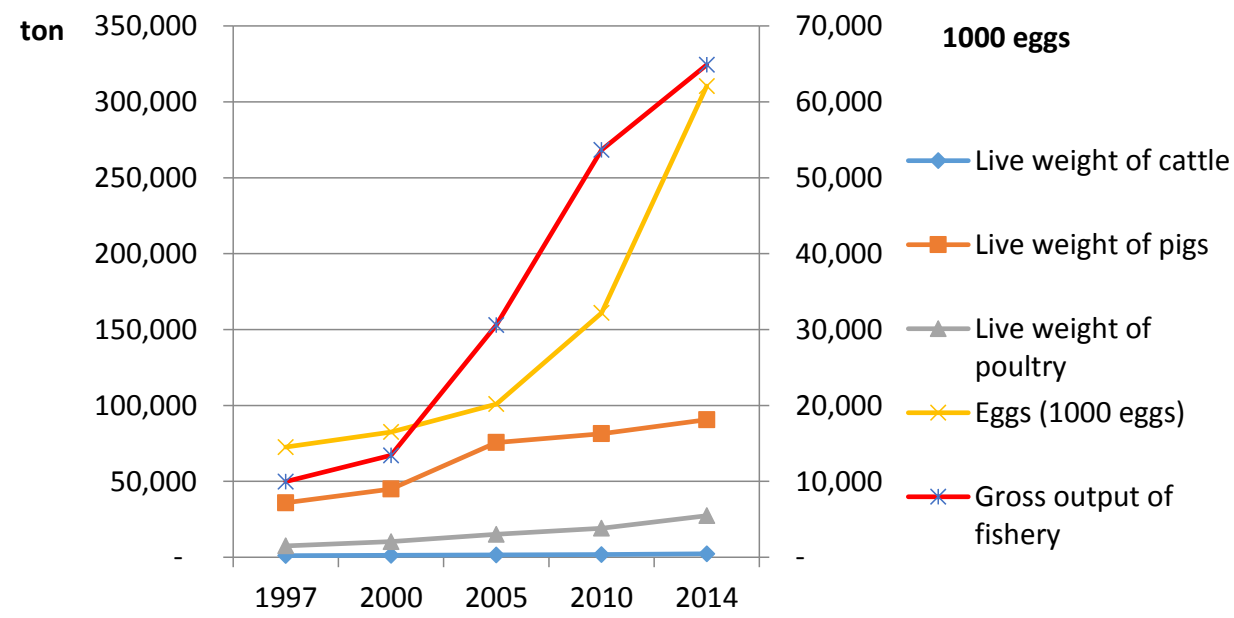

Figure 4. Changes in livestock and fish production in Hai Duong (1997-2014). Source: Hai Duong Statistics Office.

\subsection{Economic Effectiveness and Efficiency of Integrated Agriculture Aquaculture Systems}

Although, traditional VAC system appears to be the smallest scale production model among four systems, it is the most productive model. The study shows that the annual yield per sao $\left(360 \mathrm{~m}^{2}\right)$ in this model reaches $373 \mathrm{~kg}$ of fish (see Table 4); while the FS system, the largest scale of fish production, 
obtains the lowest yield of $325 \mathrm{~kg}$. This can be explained by the higher number of fish species raising in the pond of the traditional VAC model compared with other models. Households in this model use more than 6 fish species (see Table 3) allowing a combination of nutrient feeding flow in the fishpond space. For example, the excreta waste of grass carp can benefit for common carp, rohu, migral and other indigenous species. Additionally, larger fingerlings used by the households can reduce mortality rate. Furthermore, the traditional fish species can continuously grow up within two-year production cycle. This is a reason why the production cycle in the traditional VAC lasts one to two months longer compared to others (see Table 3), and it is likely to make households achieve a higher annual yield of fish production.

Regarding to household food security, the traditional VAC and New VAC systems provide a strong in-kind contribution compared to the AF and FS systems. Total value of fish for home consumption per sao $\left(360 \mathrm{~m}^{2}\right)$, the AF and FS systems are less than three to five times in comparison to the two other systems (see Table 4). However, the FS and AF systems take an advantage of food security in-cash because of higher income. It also means the AF and FS systems rely more on market than the traditional and New VAC systems when satisfying households' food security. Large proportion of fish spent on home consumption in the traditional VAC could make better nutrition for households.

The traditional VAC model is the most labour-intensive system in the fish production. This is because of diversified species of fish that require more available natural, on-farm or home-made feeds. Therefore, feeding preparation is a time consuming, for example collecting grasses for grass carp and cooking rice bran, paddy for common carp. Furthermore, fish ponds are located nearby farmers' resident houses so that family members are more convenient to participate in fish production daily.

Table 4. Annual Economic Effectiveness and Efficiency of fish production per Sao at Farms in Hai Duong province. Unit: $1000 \mathrm{VND}^{1}$.

\begin{tabular}{|c|c|c|c|c|}
\hline & $\begin{array}{l}\text { FS System } \\
\qquad(\mathrm{N}=51)\end{array}$ & $\begin{array}{l}\text { AF System } \\
\quad(\mathrm{N}=65)\end{array}$ & $\begin{array}{c}\text { New VAC } \\
\text { System }(\mathrm{N}=35)\end{array}$ & $\begin{array}{c}\text { Traditional VAC } \\
\text { System }(\mathrm{N}=16)\end{array}$ \\
\hline Global HH production ( $\mathrm{kg} /$ household) & 4727 & 4254 & 2144 & 885 \\
\hline Home consumption $(\mathrm{Kg} / \mathrm{sao})$ & 11.9 & 13.5 & 27.9 & 52.9 \\
\hline Working Labor(man-days/sao) & 14.0 & 16.4 & 32.6 & 49.6 \\
\hline Total value of fish for home consumption & 502.1 & 602.6 & 1199.0 & 1452.7 \\
\hline All variable $\operatorname{costs}^{2}$ (All Purchased Activity Direct Inputs) & 8349.9 & 9797.2 & 9305.8 & 5263.4 \\
\hline Fingerlings & 2202.9 & 2577.5 & 2995.2 & 1523.5 \\
\hline Feed & 5622.3 & 6441.1 & 5641.2 & 2823.7 \\
\hline Fertilizer & 3.6 & 1.0 & 9.4 & - \\
\hline Lime & 92.8 & 109.7 & 84.5 & 107.7 \\
\hline All Farm Fixed Costs (Except Depreciation) & 172.5 & 193.2 & 272.9 & 231.3 \\
\hline Farm Net Actual Returns & 9198.3 & $10,546.5$ & $10,562.3$ & 7818.3 \\
\hline All Capital Depreciation ${ }^{3}$ & 602.7 & 886.3 & 755.1 & 701.6 \\
\hline Farm Net Sustainable Returns of Fish & 8595.6 & 9660.3 & 9807.2 & 7116.7 \\
\hline
\end{tabular}

${ }^{1}$ Exchange rate: 1 USD $=22.500$ VND. ${ }^{2}$ The cost is excluded the family labor. ${ }^{3}$ The fixed cost is calculated based on depreciation over 10 years. Source: survey, 2015-2016.

By costs analysis, all variable costs of inputs of the traditional VAC system is the lowest. It is 5.3 million VND (235 USD) per sao in comparison with that of 8.3 million VND (370 USD) in the FS system, 9.3 million VND (410 USD) in the New VAC, and 9.8 million VND (435 USD) in the AF system (see Table 4). Feed and fingerling constitute over $90 \%$ of total variable inputs every system. In the traditional VAC, utilizing regularly agricultural by products of agriculture, wastes of off-farm activities (like alcoholic beverage production, rice milling services ... or natural resources such as grass, golden apple snail) reduces the cost of feed significantly. 
It is also found that chemicals used in the traditional VAC model is higher than the others. This is because of the scale of economies, in which households normally own small fishponds. A full bottle of chemical for fishpond treatment is not completely used for a small fishpond. Moreover, chemicals are not only used for fishpond, but also for animal husbandry, rice, vegetables production. Additionally, priority of using bio-chemicals by households in the traditional VAC model would contribute to higher input costs.

The research results reveal that the New VAC is the most efficient system with Farm Net Sustainable Returns of Fish ( 9.8 million VND or 435 USD per $360 \mathrm{~m}^{2}$ ). This system has currently been most interested and promoted by a wide range of stakeholders. The VAC system helps the farmers in obtaining higher returns, achieving the best use of on-farm inputs, lessening their dependence on purchased inputs and sustaining patterns of farm resource use. It plays an important role in food supply, job creation and sustainability of rural economy. It also provides opportunities and directions for farmers to diversify the traditional rice-based production patterns into more sustainable farming systems that enable farmers to obtain better quality of life with less environmental damage and health risk.

\subsection{Integrated Agriculture Aquaculture Systems' Income and Food Diversity}

In this study, off-farm income has not been taken into account, so that average total farm's income only consisted of values from rice cultivation, animal husbandry, aquaculture, vegetables, orchard garden and fish. By this approach, households in the AF system gained the largest annual on-farm income (100 million VND or 4400 USD), in which it is $53 \%$ of fish, $34 \%$ of livestock husbandry, $13 \%$ of cultivation. Households in the traditional and New VAC systems have similar total income and it is lower than that of AF and FS systems due to their limited agricultural land, capital investment, and some related resources. However, it is found that the fish production has contributed a major income to households in the FS, AF and New VAC systems.

In terms of household vulnerability, in the FS system, the households are more vulnerable to income compared to those in other systems. The survey showed that the income from fish of these households accounts for 82\% (Table 5) of total on-farm income (72 million VND or 3200 USD). Meanwhile, in the traditional VAC system, households are less dependent on the fish income which presents $18.8 \%$ of total on-farm income. The largest share of income in these households is from on livestock husbandry accounting for $50 \%$ of the total on-farm income. The explanation for the lower proportion of fish income in the traditional VAC system compared to the FS system results from the scale of production. Average area of aquaculture in the traditional VAC system is about 2.44 sao $\left(878 \mathrm{~m}^{2}\right)$, while that in the FS system is $14.49 \mathrm{sao}\left(5216 \mathrm{~m}^{2}\right)$.

Table 5. Total sources of on-farm income at fish farms yearly in Hai Duong province.

\begin{tabular}{|c|c|c|c|c|c|c|c|c|}
\hline & \multicolumn{2}{|c|}{ FS System } & \multicolumn{2}{|c|}{ AF System } & \multicolumn{2}{|c|}{ New VAC System } & \multicolumn{2}{|c|}{ Traditional VAC System } \\
\hline & $(N=51)$ & $\%$ & $(N=65)$ & $\%$ & $(\mathrm{~N}=35)$ & $\%$ & $(N=16)$ & $\%$ \\
\hline Rice crop & 5265.4 & 64.5 & 8171.3 & 62.40 & 6818.2 & 46.0 & $13,729.1$ & 75.6 \\
\hline Vegetable crop & - & - & 1380.4 & 10.54 & 1053.3 & 7.1 & 2189.6 & 12.1 \\
\hline Fruit crops & 2901.8 & 35.5 & 3544.0 & 27.06 & 6958.0 & 46.9 & 2238.3 & 12.3 \\
\hline Total crops & 8167.1 & 11.3 & $13,095.8$ & 12.99 & $14,829.5$ & 25.6 & $18,157.1$ & 31.1 \\
\hline $\begin{array}{l}\text { Livestock } \\
\text { husbandry }\end{array}$ & 4904.6 & 6.8 & $34,162.4$ & 33.87 & 8077.9 & 13.9 & $29,243.0$ & 50.1 \\
\hline Fish production & $58,922.8$ & 81.8 & $53,594.1$ & 53.14 & $35,024.8$ & 60.4 & $10,997.6$ & 18.8 \\
\hline Total & $71,994.5$ & 100.0 & $100,852.3$ & 100.0 & $57,932.1$ & 100.0 & $58,397.7$ & 100.0 \\
\hline
\end{tabular}

Source: survey, 2015-2016.

More interestingly, households in the traditional VAC system earn more income from rice compared to other systems because of preserving a larger agricultural land for rice production. It showed that income from rice crop reaches 13.73 million VND (610 USD) per year on average, 
following by 8.13 million VND (361 USD) in the AF system, 6.83 million VND (304 USD) in the New VAC system, and 5.27 million VND (234 USD) in the FS system. The income from animal husbandry (29.243 thousand VND or 1.300 USD) is also higher than that of the New VAC system because households in the traditional VAC model use less commercial feeds that reduce production costs. In fact, the traditional VAC model can diversify the off-farm activities and maximize the efficiency of agricultural production by effectively utilizing the household's available resources for both farming and food processing activities. On the other hand, the traditional VAC system is less vulnerable to food security than that of other systems.

\section{Conclusions}

Over time, integrated agriculture aquaculture systems are dynamic, diverse and subject to economic and environmental changes. The development of integrated agriculture aquaculture systems in the Red River Delta has shown the evolution from low-input on-farm integrated systems to high input off-farm integrated and commercial systems, supplying considerable amount of fish to rural and urban consumers. The integrated aquaculture systems play a significant role in supplying and diversifying food and foodstuffs for the local communities. The traditional VAC, New VAC and AF systems have been becoming more important in northern Vietnam for food security and rural development.

FS system is less efficient and stable in terms of resource-utilization and economic returns. With similar levels of farm resources or capital investment, households operating the AF system are able to obtain a much more monetary return than that of the FS system. The traditional VAC and the New VAC systems are more economic efficiency and effectiveness than the two other systems. In addition, households operating VAC systems can diversify their on-farm incomes which are considered to be a reasonable strategy to risk averse in the agricultural activities.

Aquaculture integration has been a considerable potential within the VAC systems in the region and can make a significant contribution to livelihood development of poor farmers in developing countries who have limited accesses to farming resources, investment capital and face challenges to ensure food security. A further research on understanding fully VAC systems at larger scale with a focus on economic, environmental resource-utilization, and social benefits will be important to highlight the contribution of VAC systems to poverty reduction and improvements to livelihoods, as well as food security for most rural small-scale farmers in developing countries..

Under the traditional VAC system, the area of rice production still accounts for a major proportion of agricultural land. This is a fundamental basis for rural areas in Vietnam to ensure for food security not only in short term but also in long term. In the context of rapid agricultural land acquisition for the urbanization and industrialization process, both traditional and New VAC systems are likely sustainable food systems for smallholders to ensure food security in Hai Duong province. These systems could be an answer for the debate question of the sustainable food production system in the future and how to feed the growing population under continuously decreasing areas of cultivated land.

Author Contributions: Philippe Lebailly is the promoter of this $\mathrm{PhD}$ research. He provided instruction for the research design and approach, and editing of the paper. TRAN Huu Cuong is the co-promoter of this PhD research, based in Vietnam. He provided comments for the research design, approach, and the paper. TRAN Thi Nang Thu provided suggestions and comments for the research design, approach, and the paper. NGUYEN Van Huong conducted surveys in Vietnam, wrote the paper and took responsibility for the paper improvement and responded to the journal reviewers and the Editorial Board.

Conflicts of Interest: The authors declare no conflict of interest. 


\section{Appendix A}

Table A1. Freshwater Fish Production System (FFPS) Characteristics in Hai Duong.

\begin{tabular}{|c|c|c|c|c|c|}
\hline FFPS & Location & $\begin{array}{l}\text { Integrated } \\
\text { Levels between } \\
\text { Sub-Systems }\end{array}$ & $\begin{array}{l}\text { Farm } \\
\text { Household } \\
\text { Situations }\end{array}$ & Animal Husbandry & Horticulture \\
\hline $\begin{array}{l}\text { Intensive orchard-very } \\
\text { low input aquaculture } \\
\text { (Traditional VAC system) }\end{array}$ & Inside village & $\begin{array}{l}\text { High with closed } \\
\text { available nutrient } \\
\text { flow of food }\end{array}$ & $\begin{array}{l}\text { Experience in } \\
\text { aquaculture } \\
\text { production, } \\
\text { prevalence of } \\
\text { rice production }\end{array}$ & $\begin{array}{l}\text { With or without } \\
\text { medium pig } \\
\text { production } \\
(5-15 \text { pigs/HH), or } \\
\text { small to medium scale } \\
\text { poultry production }\end{array}$ & $\begin{array}{l}\text { Small/medium } \\
\text { number and } \\
\text { area of } \\
\text { perennial trees }\end{array}$ \\
\hline $\begin{array}{c}\text { Intensive orchard-low } \\
\text { input aquaculture (New } \\
\text { VAC system) }\end{array}$ & Outside village & $\begin{array}{l}\text { High with closed } \\
\text { nutrient flow of } \\
\text { food }\end{array}$ & $\begin{array}{l}\text { Less experience } \\
\text { in aquaculture } \\
\text { production }\end{array}$ & $\begin{array}{l}\text { With or without small } \\
\text { pig production } \\
(1-10 \text { pigs } / \mathrm{HH}), \text { or } \\
\text { small to medium scale } \\
\text { poultry production }\end{array}$ & $\begin{array}{l}\text { Large number } \\
\text { and area of } \\
\text { perennial trees }\end{array}$ \\
\hline $\begin{array}{l}\text { Semi-intensive } \\
\text { orchard-medium input } \\
\text { aquaculture (Animal + } \\
\text { Fish production-AF } \\
\text { system) }\end{array}$ & Outside village & Medium & $\begin{array}{l}\text { Experience in } \\
\text { aquaculture } \\
\text { and animal } \\
\text { production }\end{array}$ & $\begin{array}{l}\text { With or without } \\
\text { medium pig } \\
\text { production } \\
\text { (10-50 pigs/HH) or } \\
\text { commercial poultry } \\
\text { production }\end{array}$ & $\begin{array}{l}\text { Small number } \\
\text { and area of } \\
\text { perennial trees }\end{array}$ \\
\hline $\begin{array}{l}\text { Extensive orchard high } \\
\text { input aquaculture } \\
\text { (Commercially intensive } \\
\text { fish production-FS } \\
\text { system) }\end{array}$ & Outside village & $\begin{array}{l}\text { Low with more } \\
\text { external } \\
\text { supplement of } \\
\text { food flow }\end{array}$ & $\begin{array}{l}\text { Experience in } \\
\text { aquaculture }\end{array}$ & $\begin{array}{l}\text { Self-subsistence } \\
\text { poultry production }\end{array}$ & $\begin{array}{l}\text { Small number } \\
\text { of perennial } \\
\text { trees }\end{array}$ \\
\hline
\end{tabular}

\section{References}

1. Dey, M.M.; Ahmed, M. Aquaculture-Food and livelihoods for the poor in Asia: A brief overview of the issues. Aquac. Econ. Manag. 2005, 9, 1-10. [CrossRef]

2. Dey, M.M. Strategies and Options for Increasing and Sustaining Fisheries and Aquaculture Production to Benefit Poorer Households in Asia; WorldFish: Penang, Malaysia, 2008; Volume 1823.

3. Mishra, V.; Ray, R. Dietary diversity, food security and undernourishment: The Vietnamese evidence. Asian Econ. J. 2009, 23, 225-247. [CrossRef]

4. Prein, M.; Ahmed, M. Integration of aquaculture into smallholder farming systems for improved food security and household nutrition. Food Nutr. Bull. 2000, 21, 466-471. [CrossRef]

5. Tacon, A. Contribution to Food Fish Supplies; FAO Fisheries Circular: Rome, Italy, 1997; pp. 17-21.

6. Belton, B.; Little, D.C. Contemporary visions for small-scale aquaculture. In Contemporary Visions for World Small-Scale Fisheries; Chuenpagdee, R., Ed.; Eburon: Delft, The Netherlands, 2011.

7. Prein, M. Integration of aquaculture into crop-animal systems in Asia. Agric. Syst. 2002, 71, 127-146. [CrossRef]

8. Little, D.C.; Belton, B.; Beveridge, M.; Bush, S.; Dabaddie, L.; Demaine, H.; Edwards, P.; Haque, M.; Kibria, G.; Morales, E. Alleviating poverty through aquaculture: Progress, opportunities and improvements. In Proceedings of the Global Conference of Aquaculture 2010: Farming the Waters for People and Food, Phuket, Thailand, 22-25 September 2010; pp. 719-783.

9. Gyalog, G.; Oláh, J.; Békefi, E.; Lukácsik, M.; Popp, J. Constraining factors in hungarian carp farming: An econometric perspective. Sustainability 2017, 9, 2111. [CrossRef]

10. Edwards, P. Aquaculture, Poverty Impacts and Livelihoods; Overseas Development Institute: London, UK, 2000.

11. Blythe, J.; Sulu, R.; Harohau, D.; Weeks, R.; Schwarz, A.-M.; Mills, D.; Phillips, M. Social dynamics shaping the diffusion of sustainable aquaculture innovations in the Solomon Islands. Sustainability 2017, 9, 126. [CrossRef]

12. Luu, L.T. Vietnam: Status of implementation of the resolution and plan of action on aquaculture. In Sustainable Aquaculture Development for Food Security in Southeast Asia Towards 2020, Proceedings of the Regional Technical Consultation on Sustainable Aquaculture Development in Southeast Asia Towards 2020, Bangkok, Thailand, 17-19 March 2010; Acosta, B.O., Coloso, R.M., de Jesus-Ayson, E.G.T., Toledo, J.D., Eds.; SEAFDEC Aquaculture Department: Iloilo, Philippines, 2011; pp. 129-133. 
13. Allen, T.; Prosperi, P.; Cogill, B.; Flichman, G. Agricultural biodiversity, social-ecological systems and sustainable diets. Proc. Nutr. Soc. 2014, 73, 498-508. [CrossRef] [PubMed]

14. Luu, L. The VAC system in Northern Viet Nam. In FAO Fisheries Technical Paper; Food and Agriculture Organization: Rome, Italy, 2001; pp. 29-32.

15. Ruddle, K.; Zhong, G. Integrated Agriculture-Aquaculture in South China: The Dike-Pond System of the Zhujiang Delta; Cambridge University Press(CUP) Archive: Cambridge, UK, 1988.

16. Nhan, D.K. The Role of a Fish Pond in Optimizing Nutrient Flows in Integrated Agriculture-Aquaculture Farming Systems. Ph.D. Thesis, Wageningen University, Wageningen, The Netherlands, 2007.

17. Luu, L.T. Sustainable Aquaculture for Poverty Alleviation (SAPA): A New Rural Development Strategy for Viet Nam; Part II; FAO Aquaculture Newsletter (FAO): Rome, Italy, 2001.

18. Pekar, F.; Be, N.; Long, D.; Cong, N.; Dung, D.; Olah, J. Eco-technological analysis of fish farming households in the Mekong Delta, Vietnam. In Rural Aquaculture; CABI Publishing: Wallingford, UK, 2002; pp. 77-95.

19. Misui, H.; Horiuchi, H. Classification of vac farming systems: A case study of Bac Son Commune in the Red River Delta, Vietnam. J. Agric. Dev. Stud. Jpn. 2006, 17, 1-6.

20. Mohan Dey, M.; Rab, M.A.; Paraguas, F.J.; Bhatta, R.; Ferdous Alam, M.; Koeshendrajana, S.; Ahmed, M. Status and economics of freshwater aquaculture in selected countries of Asia. Aquac. Econ. Manag. 2005, 9, 11-37. [CrossRef]

21. Ahmed, M.; Lorica, M.H. Improving developing country food security through aquaculture development-Lessons from Asia. Food Policy 2002, 27, 125-141. [CrossRef]

22. Ruddle, K.; Prein, M. Assessing the potential nutritional and household economic benefits of developing integrated farming systems, Integrated fish farming. In Proceedings of the International Workshop Held in Wuxi, Wuxi, China, 11-15 October 1994; pp. 11-15.

23. Sultana, P.; Khan, A.F. Aquaculture Extension Impacts in Bangladesh: A Case Study from Kapasia, Gazipur; WorldFish: Penang, Malaysia, 2005; Volume 1717.

24. Thilsted, S.H.; Roos, N. Policy Issues on Isheries in Relation to Food and Nutrition Security; Fisheries Policy Research; Food and Agriculture Organization of the United Nations: Rome, Italy, 1999.

25. Thompson, P.; Sultana, P.; Nuruzzaman, M.; Khan, A.; Islam, S. Fisheries Extension Evaluation Project; Final Report; ICLARM - The WorldFish Center and Bangladesh DOF: Dhaka, Bangladesh, 2000.

26. Godfray, H.C.J.; Beddington, J.R.; Crute, I.R.; Haddad, L.; Lawrence, D.; Muir, J.F.; Pretty, J.; Robinson, S.; Thomas, S.M.; Toulmin, C. Food security: The challenge of feeding 9 billion people. Science 2010, 327, 812-818. [CrossRef] [PubMed]

27. Food and Agriculture Organization(FAO). The Role of Aquaculture in Sustainable Development; Thirty-Fourth Session; FAO: Rome, Italy, 2007.

28. Food and Agriculture Organization(FAO). Food Balance Sheets. Vietnam. Available online: http:/ / faostat. fao.org/site/368/DesktopDefault.aspx?PageID=368\#ancor (accessed on 14 September 2015).

29. Food and Agriculture Organization FAO. Aquaculture Production 1950-2009 (Data Set for Fishstat Plus). Fao Fisheries Department, Fishery Data and Statistics Unit; FAO: Rome, Italy, 2011.

30. Lebailly, P.; Peemans, J.-P.; Vu Dinh, T.; Diepart, J.-C.; Dupuis, D.; Mai Lan, P.; Nguyen Mau, D.; Nguyen Thi, D.; Verhaegen, E.; Han Quang, H. Développement Rural et Petite Paysannerie en Asie du Sud-Est: Leçons D'expériences au Vietnam et au Cambodge (Rural Development and Small Farmers in South East Asia: Lessons of Experiences in Vietnam and Cambodia); L'Harmattan: Paris, France, 2015.

31. Hai Duong Statistic Office (HDSO). Hai Duong Statistical Yearbook; Statistical Publishing House: Ha Noi, Vietnam, 2005.

32. Hai Duong Statistic Office (HDSO). Hai Duong Statistical Yearbook; Statistical Publishing House: Ha Noi, Vietnam, 1999.

33. Hai Duong Statistic Office (HDSO). Hai Duong Statistical Yearbook; Statistical Publishing House: Ha Noi, Vietnam, 2014.

34. McConnell, D.J.; Dillon, J.L. Farm Management for Asia: A systems Approach; Food \& Agriculture Organization of the United Nation: Rome, Italy, 1997.

(C) 2018 by the authors. Licensee MDPI, Basel, Switzerland. This article is an open access article distributed under the terms and conditions of the Creative Commons Attribution (CC BY) license (http:/ / creativecommons.org/licenses/by/4.0/). 